\title{
壳聚糖固载氧化亚铜催化 $\mathrm{C}$ - $\mathrm{O}$ 和 $\mathrm{C}$ - $\mathrm{N}$ 偶联反应
}

\author{
钱存卫* 朱文倩 刘俊龙 王雪敏 仇立千* \\ (盐城师范学院化学与环境工程学院 盐城 224051)
}

\begin{abstract}
摘要 制备了四种壳聚糖固载的铜盐催化剂, 以这四种催化剂尝试催化 $\mathrm{C}-\mathrm{O}$ 和 $\mathrm{C}-\mathrm{N}$ 的偶联反应, 实验结果显示, 壳 聚糖固载的氧化亚铜可以高效催化芳基卤代烃与酚及含氮杂环的偶联反应，且该方法的底物适应性广. 实验结果还显 示, 该催化剂具有易回收、可重复利用的优点，且多次重复利用后该催化剂的催化活性未明显减弱.
\end{abstract}

关键词 壳聚糖@ $\mathrm{Cu}_{2} \mathrm{O}$; 合成; 催化; 偶联反应

\section{Chitosan@ $\mathrm{Cu}_{2} \mathrm{O}$ as A Facile, Efficient and Reusable Catalyst for Ligand-Free $\mathrm{C}-\mathrm{O}$ and $\mathrm{C}-\mathrm{N}$ Coupling}

\author{
Qian, Cunwei* Zhu, Wenqian Liu, Junlong Wang, Xuemin Qiu, Ligan* \\ (School of Chemical and Environmental Engineering, Yancheng Teachers College, Yancheng 224051)
}

\begin{abstract}
The coupling reactions of phenols and nitrogen hetereocycles with aryl halide were catalyzed by a highly active, readily available and easily recoverable heterogeneous $\mathrm{Cu}$ catalyst which was prepared by simply stirring an suspension of chitosan in solvent with copper compound. The result showed that chitosan@ $\mathrm{Cu}_{2} \mathrm{O}$ catalyst catalyzed the coupling reactions of aryl halides with phenols and nitrogen hetereocycles to readily give the corresponding products in moderate to excellent yields. The highly active catalyst can be reused many times without losing its catalytic activity.

Keywords chitosan@Cu catalyst; synthesize; catalyze; Cross-coupling
\end{abstract}

\section{Introduction}

$N$-Arylazoles and aryl ethers are valuable compounds in organic synthesis, pharmaceutical, or biological areas. ${ }^{[1,2]}$ One of the most common methods for their preparation is the Ullmann-type coupling reaction. ${ }^{[3]}$ On account of the problems associated with this noteworthy reaction such as long reaction time, high temperature $\left(>200{ }^{\circ} \mathrm{C}\right)$ and stoichiometric amount of copper required as catalyst, organic chemists made persevering efforts to set the stage for satisfactory reaction conditions to overcome this downside. In the past years, significant advances have been achieved for the copper-catalyzed synthesis of $N$-arylazoles and aryl ethers by use of the ligands explored. ${ }^{[4]}$ With the carefully selected combinations of a catalytic amount of copper sources, bases and ligands, aryl bromides and aryl iodides had been reported to couple with phenols and imidazoles with excellent yields under mild conditions. ${ }^{[5 \sim 16]}$ Although these homogeneous copper-catalysts were successful for coupling reactions, they had some inherent limitations such as corrosion, toxicity, difficulty in catalyst handling and separation from the reaction system and the recycling of solid waste. These shortcomings also limit their massive applications in industrial fields. Immobilizing the copper catalyst on a heterogeneous support is one of the main strategies to circumvent the aforementioned problems. ${ }^{[17]}$ Therefore, various heterogeneous supports have been applied to immobile types of copper catalysts to improve these coupling reactions, such as polysaccharides, ${ }^{[18]}$ graphite ${ }^{[19,20]}$ silica, ${ }^{[21]}$ magnetic materials, ${ }^{[22,23]}$ maghemite ${ }^{[24]}$ and functionalized MWCNTs. ${ }^{[25]}$ Among these supports, recently, chitosan (CS) has attracted significant attention owing to its green and essential roles in transition metal catalyzed reactions. ${ }^{[26]}$ Several groups have reported the catalytic activity of chitosan-supported metal complexes used as catalysts for $\mathrm{C}-\mathrm{C}$ bond forming reactions such as the Suzuki cross-coupling reaction (CS-supported Pd catalyst), ${ }^{[27]}$ Henry reaction (CS-supported Ti catalyst), ${ }^{[28]}$ hydroformylation reaction (CS-supported Rh catalyst ${ }^{[29]}$, for $\mathrm{C}-\mathrm{N}$ and $\mathrm{C}-\mathrm{S}$ bonds forming reactions

* Corresponding authors. E-mail: qiancunwei@163.com; chemistry_wmy@163.com

Received December 2, 2018; revised April 4, 2019; published online April 16, 2019

Project supported by the Natural Science Foundation of the Jiangsu Higher Education Institutions of China (No. 14JKD150009) and the Key Projects of Innovation and Entrepreneurship Training Program for College Students in Jiangsu Province (No. 201710324003Z). 
(CS-supported Cu catalyst). ${ }^{[30-33]}$ As far as we know, there are very few examples available involving it in coppercatalyzed arylation of phenols and azoles. Herein we report that a series of CS-supported $\mathrm{Cu}$ catalysts were prepared and applied in arylations of phenols and azoles under ligand-free conditions.

\section{Results and discussion}

The investigation was initiated by using the coupling of bromobenzene and phenol as a model reaction. Initially we evaluated the catalytic efficiency of different catalysts (A, $\mathbf{B}, \mathbf{C}$ and $\mathbf{D})$ for the $O$-arylation of phenol with bromobenzene. As shown in Table 1 (Entries $1 \sim 4$ ), catalyst $\mathbf{A}$ $\left(\mathrm{CS} @ \mathrm{Cu}_{2} \mathrm{O}\right)$ showed better catalytic potency than catalyst $\mathbf{B}, \mathbf{C}$ and $\mathbf{D}$ for the coupling of bromobenzene with phenol. Screening a range of solvent showed DMF to be much more efficacious than other solvents (such as toluene, $\mathrm{CH}_{3} \mathrm{CN}$ and DMSO) (Table 1, Entries 1 vs $5 \sim 8$ ). To know the effect of bases on the outcome of the reaction, different bases were employed in the coupling reaction and it was observed that $\mathrm{K}_{3} \mathrm{PO}_{4}$ was the most effective base (Table 1, Entries 1 and 9 13). Therefore $\mathrm{K}_{3} \mathrm{PO}_{4}$ was used in subsequent reactions as the base. For further optimization of the reaction conditions, increasing yields of the coupling product were observed by simply increasing the dosage of $\mathrm{K}_{3} \mathrm{PO}_{4}$ to 3.0 equiv (Table 1, Entry 14). As previously reported, ${ }^{[11]}$ the use of 2.0 equiv. of phenol was propitious to the increasement of yields, and resulted in $95 \%$ yield (Table 1, Entry 15). It was that the coupling reaction of phenol

Table $1 O$-Arylation of phenol with bromobenzene: optimization of the reaction conditions ${ }^{a}$

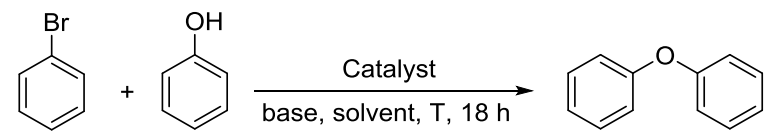

Catalyst: A CS@Cu $2 \mathrm{O}$, B CS@Cu(OAc) 2 , C CS@CusO ${ }_{4}$, D CS@Cul

\begin{tabular}{|c|c|c|c|c|}
\hline Entry & Catalyst & Solvent & Base & Yield $^{b} / \%$ \\
\hline 1 & $\mathbf{A}$ & DMF & $\mathrm{K}_{3} \mathrm{PO}_{4}$ & 61 \\
\hline 2 & B & DMF & $\mathrm{K}_{3} \mathrm{PO}_{4}$ & 48 \\
\hline 3 & $\mathrm{C}$ & DMF & $\mathrm{K}_{3} \mathrm{PO}_{4}$ & 40 \\
\hline 4 & D & DMF & $\mathrm{K}_{3} \mathrm{PO}_{4}$ & 37 \\
\hline 5 & $\mathbf{A}$ & $\mathrm{CH}_{3} \mathrm{CN}$ & $\mathrm{K}_{3} \mathrm{PO}_{4}$ & 38 \\
\hline 6 & $\mathbf{A}$ & DMSO & $\mathrm{K}_{3} \mathrm{PO}_{4}$ & 58 \\
\hline 7 & $\mathbf{A}$ & Dioxane & $\mathrm{K}_{3} \mathrm{PO}_{4}$ & 40 \\
\hline 8 & $\mathbf{A}$ & Toluene & $\mathrm{K}_{3} \mathrm{PO}_{4}$ & 18 \\
\hline 9 & $\mathbf{A}$ & DMF & $\mathrm{Et}_{3} \mathrm{~N}$ & 23 \\
\hline 10 & $\mathbf{A}$ & DMF & $\mathrm{Na}_{2} \mathrm{CO}_{3}$ & 23 \\
\hline 11 & $\mathbf{A}$ & DMF & $\mathrm{NaAcO}$ & 24 \\
\hline 12 & $\mathbf{A}$ & DMF & $\mathrm{Na}_{3} \mathrm{PO}_{4}$ & 43 \\
\hline 13 & A & DMF & $\mathrm{K}_{2} \mathrm{CO}_{3}$ & 50 \\
\hline $14^{c}$ & A & DMF & $\mathrm{K}_{3} \mathrm{PO}_{4}$ & 82 \\
\hline $15^{c, d}$ & $\mathbf{A}$ & DMF & $\mathrm{K}_{3} \mathrm{PO}_{4}$ & 95 \\
\hline
\end{tabular}

${ }^{a}$ General reaction conditions: $1.5 \mathrm{mmol}$ of phenol, $1.0 \mathrm{mmol}$ of bromobenzene, $1 \mathrm{~mol} \%[\mathrm{Cu}], 2.0 \mathrm{mmol}$ of potassium phosphate, $1 \mathrm{~mL}$ of anhydrous solvent. ${ }^{b}$ Isolated yield. ${ }^{c} 3.0 \mathrm{mmol}$ of potassium phosphate. ${ }^{d} 2 \mathrm{mmol}$ of phenol.
(2.0 mmol) with bromobenzene $(1 \mathrm{mmol})$ gave the best yield in the presence of $0.5 \mathrm{~mol} \% \mathrm{Cu}_{2} \mathrm{O}\left(\mathrm{CS} @ \mathrm{Cu}_{2} \mathrm{O}\right)$ and $300 \mathrm{~mol} \%$ of $\mathrm{K}_{3} \mathrm{PO}_{4}$ as base in DMF at $120{ }^{\circ} \mathrm{C}$ under an Ar atmosphere.

The scope of the copper-catalyzed $\mathrm{C}-\mathrm{O}$ bond formation was explored by using a variety of aryl bromides or aryl chlorides with substituted phenols under the optimized conditions. The results are listed in Table 2. As shown in Table 2, the coupling reactions were performed well for all the aryl bromides examined with excellent yields. As previously reported, ${ }^{[11]}$ aryl chlorides displayed lower reactivity than aryl bromides in the coupling reactions (Table 2). As summarized in Table 2, less active aryl chlorides were also successfully coupled with various phenols in good yields. The results clearly revealed that an electron-withdrawing group in the aryl chlorides favored the coupling reactions, however an electron-releasing group in the aryl chlorides went against the coupling reactions. For example, 4-chlorotoluene could be coupled with various phenols to give the products in $61 \% \sim 69 \%$ yields (Table 2, Entries 4 and 5), yet $p$-chloroacetophenone afforded the corresponding products in $68 \% \sim 76 \%$ yields (Table 2, Entries $6 \sim 7$ ). The results revealed that the $O$-arylation of electron-rich phenols with aryl chlorides only resulted in good product yields (69\% 74\%) (Table 2, Entries 1, 3 and 4). The $O$-arylation of 4-chlorophenol with aryl chlorides gave good product yields $(61 \% \sim 68 \%$ ) (Table 2, Entries 5 and 7 ), because substituent group $(\mathrm{Cl})$ only possess a weak electron-withdrawing ability. The coupling of 2-naphthol with aryl chlorides was found to proceed in good yields (Table 2, Entry 2).

Because the development of an effective catalytic system for the $\mathrm{C}-\mathrm{N}$ coupling of $\mathrm{N}$-hetereocycles (i.e. imidazole, 1,2,4-triazole, benzimidazole and indole) is still far from being satisfactory, this optimized conditions also were employed in this reaction. The results are summarized in Table 3 . We were delighted to find that the $\mathrm{N}$-arylation of $\mathrm{N}$-hetereocycles with various aryl iodides proceeded smoothly to give the corresponding products in moderate to excellent yields (Table 3, Entries $1 \sim 9$ and $13 \sim 15)$. The results showed that the electron-rich aryl halides went against the $\mathrm{C}-\mathrm{N}$ coupling of $N$-hetereocycles with various aryl iodides (Table 3 , Entries $1 \sim 3$ vs $4 \sim 9$ ). Whereas the coupling of $N$-hetereocycles with 4-bromobenzonitrile gave excellent product yields $(87 \%$ $93 \%$ ), because substituent group (CN) possesses an electron-withdrawing ability (Table 3, Entries 10 12). As illustrated in Table 3, benzimidazole and indole seemed to be more difficult to react with aryl iodides compared to imidazole and 1,2,4-triazole. The result showed that the reaction of benzimidazole and indole with various aryl iodide gave the corresponding products in moderate to good yields (Table 3, Entries 3, 6, 7 and 9). The $N$-arylation of various $N$-heterocycles and 2-iodotoluene gave only moderate product yields $(50 \% \sim 65 \%$ ) (Table 3, Entries $13 \sim 15$ ), which might be attributable to the influence of steric hindrance. As previously reported, ${ }^{[11]}$ aryl bromides 
Table 2 CS@ $\mathrm{Cu}_{2} \mathrm{O}$-catalyzed coupling reaction of aryl bromide/chloride with phenols ${ }^{a}$

$$
\begin{aligned}
& \mathrm{Ar}^{1}-\mathrm{X}+\mathrm{Ar}^{2}-\mathrm{OH} \frac{\mathrm{CS} @ \mathrm{Cu}_{2} \mathrm{O}}{\mathrm{DMF}, 110^{\circ} \mathrm{C}, \mathrm{K}_{3} \mathrm{PO}_{4}, 18 \mathrm{~h}} \mathrm{Ar}^{1{ }^{1}} \mathrm{Ar}^{2} \\
& \mathrm{X}=\mathrm{Br}, \mathrm{Cl}
\end{aligned}
$$

Entry

${ }^{a}$ Unless otherwise stated. General reaction conditions: $2.0 \mathrm{mmol}$ of phenol, $1.0 \mathrm{mmol}$ of $\mathrm{ArBr}, 0.5 \mathrm{~mol} \% \mathrm{CS} @ \mathrm{Cu}_{2} \mathrm{O}, 3.0 \mathrm{mmol}$ of $\mathrm{K}_{3} \mathrm{PO}_{4}, 0.5 \mathrm{~mL}$ of anhydrous $\mathrm{DMF}$ under $\mathrm{Ar}$ atmosphere for $18 \mathrm{~h} .{ }^{b}$ Isolated yield.

displayed lower reactivity than aryl iodides in the coupling reactions (Table 3).

To explore the reusability of $\mathrm{CS} @ \mathrm{Cu}_{2} \mathrm{O}$, the coupling reaction of phenol with chlorobenzene was chosen as a model reaction. As shown in Figure 1, $\mathrm{CS} @ \mathrm{Cu}_{2} \mathrm{O}$ are recyclable without obvious loss of activity. In each cycle, the catalyst was recovered by filtration, washed with ethylacetate $(3 \sim 5 \mathrm{~mL})$ and then dried under reduced pressure. After $\mathrm{CS} @ \mathrm{Cu}_{2} \mathrm{O}$ was recovered fifth times, its copper content was determined to be $1.82 \mathrm{mmol} / \mathrm{g}$, which was almost equal to that of the newly prepared catalyst. These result clearly reveals the heterogeneous nature of the catalyst.

\section{Conclusions}

In conclusion, a simple, general and efficient procedure is described for the cross-coupling of nitrogen and oxygen nucleophiles with aryl halide to readily give the corresponding products in good to excellent yields and with a wide range of functional group tolerance under ligand-free conditions. This catalyst is air-stable, inexpensive and easy to prepare and easy to recover by simple filtration. The reusability of this catalyst is high and the catalyst can be reused four times without significant decrease in its catalytic activity. Further applications of this catalyst to other transformations are currently under investigation. 
Table $3 \mathrm{CS} @ \mathrm{Cu}_{2} \mathrm{O}$-catalyzed reactions of $N$-heterocyclic amines with aryl bromide/iodides ${ }^{a}$

$$
\text { 学 }
$$

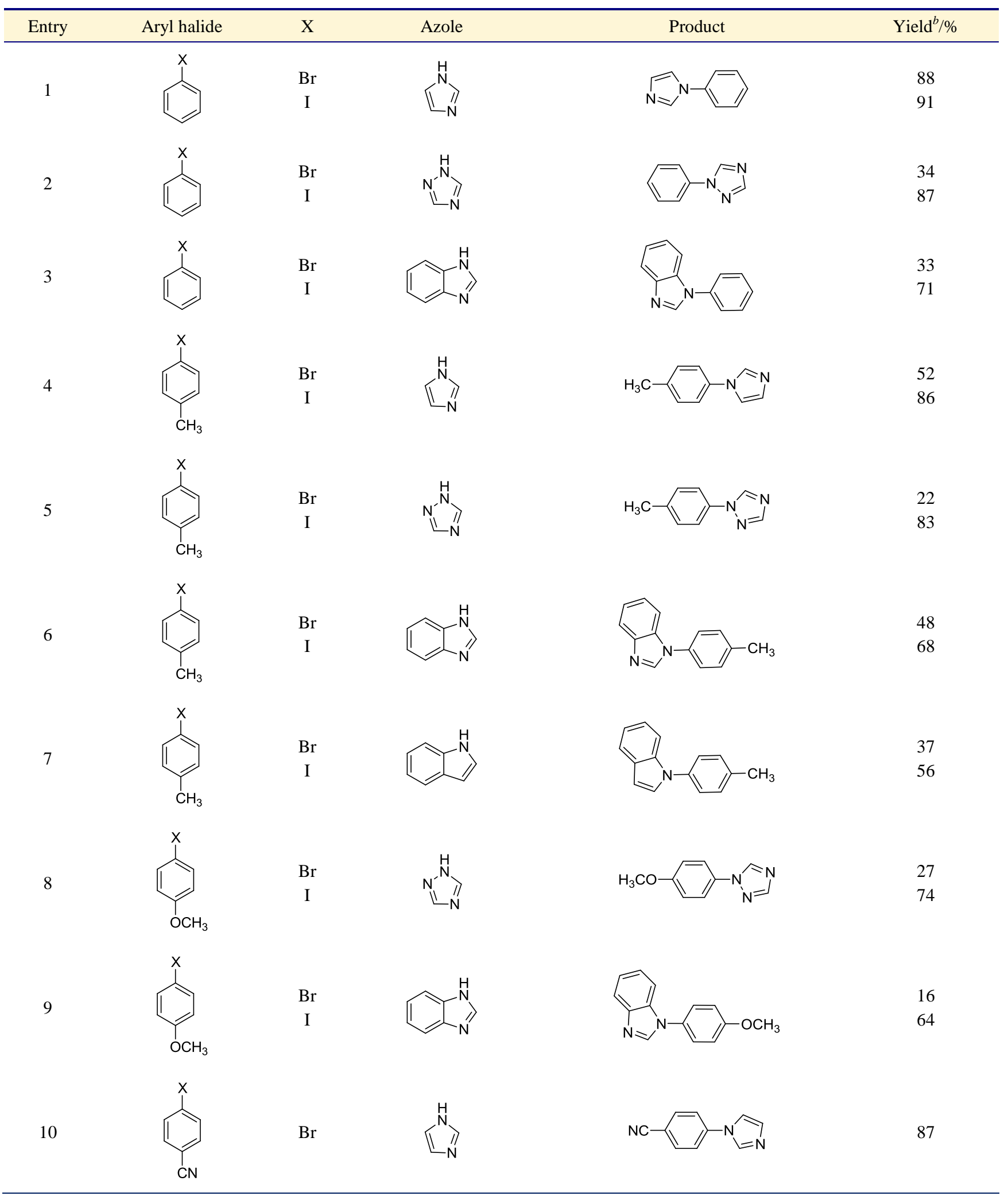


Continued

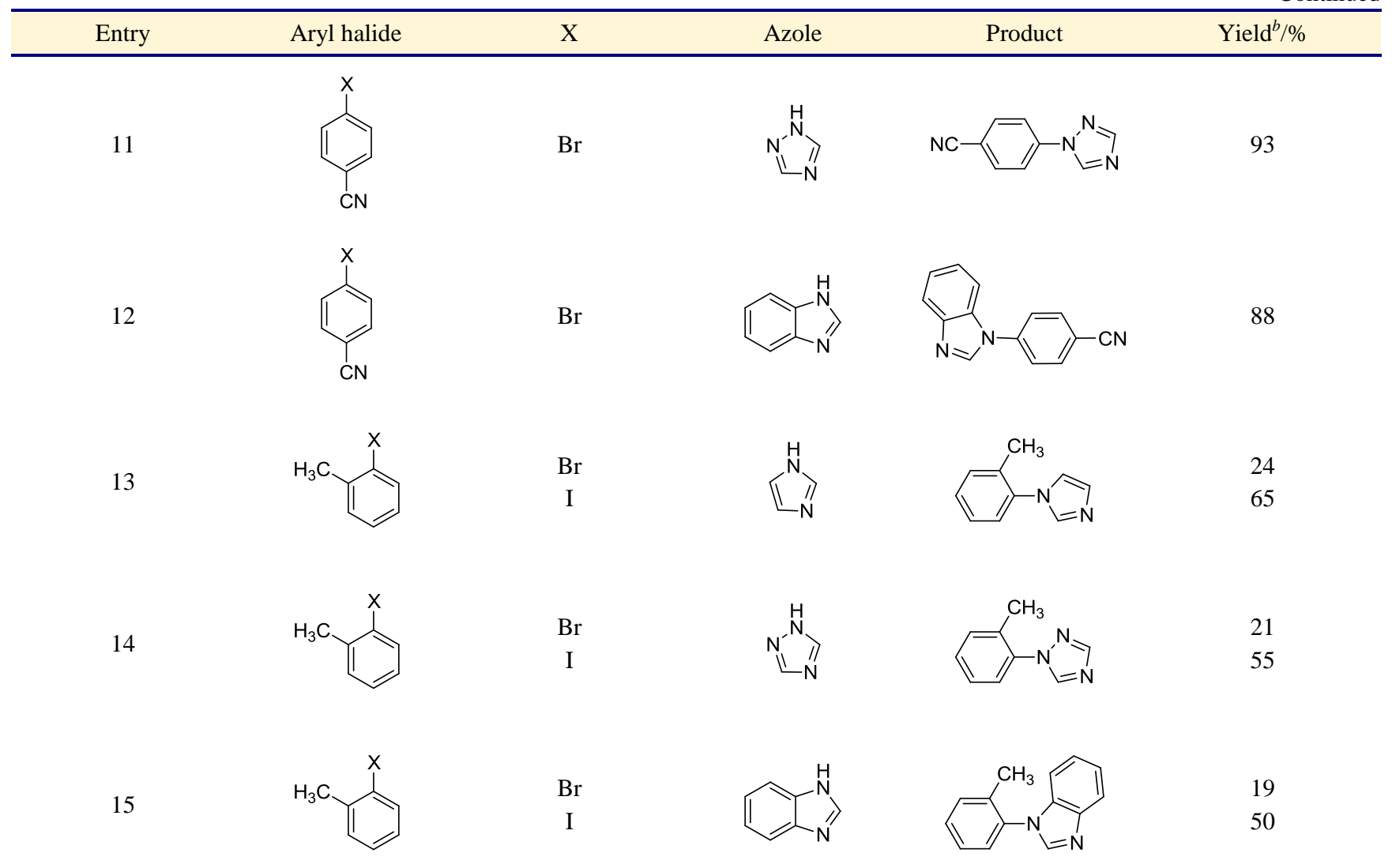

${ }^{a}$ Unless otherwise stated. General reaction conditions: $2.0 \mathrm{mmol}$ of $N$-heterocyclic amines, $1.0 \mathrm{mmol}$ of $\mathrm{ArBr}, 0.5 \mathrm{~mol} \% \mathrm{CS}_{0} @ \mathrm{Cu}_{2} \mathrm{O}, 3.0{\mathrm{mmol} \mathrm{of} \mathrm{K}_{3} \mathrm{PO}}_{4}, 0.5 \mathrm{~mL}$ of anhydrous DMF under Ar atmosphere for $18 \mathrm{~h} .{ }^{b}$ Isolated yield.

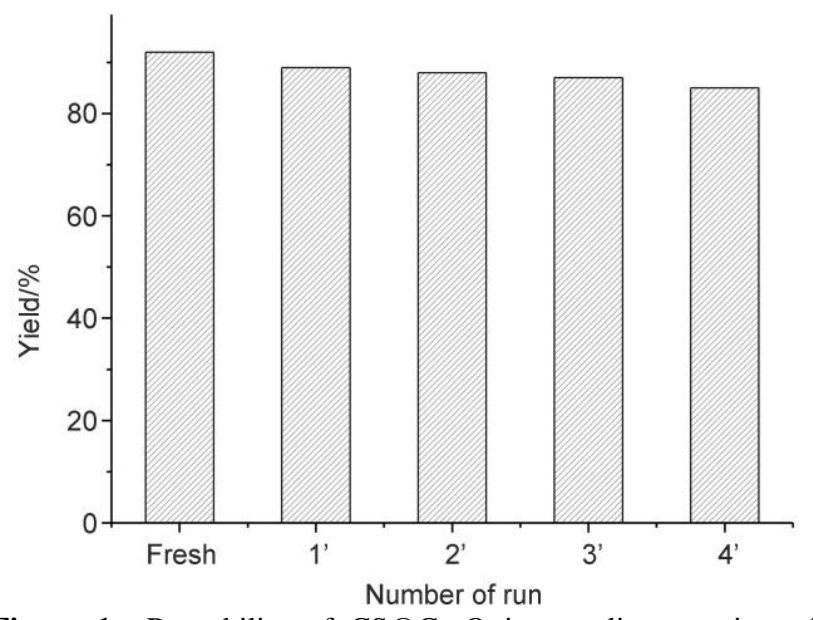

Figure 1 Reusability of $\mathrm{CS} @ \mathrm{Cu}_{2} \mathrm{O}$ in coupling reaction of chlorobenzene with phenol

\section{Experimental section}

\subsection{Materials and methods}

Reagents were obtained from commercial suppliers and used without further purification unless otherwise noted. All reactions were carried out in reaction tube under argon atmosphere. Thin layer chromatography (TLC) was performed using Qingdao silica gel (silica gel GF254). TLC plates were analyzed by ultraviolet (UV) light. ${ }^{1} \mathrm{H}$ NMR and ${ }^{13} \mathrm{C}$ NMR spectra were measured on a Bruker AV 400
$\mathrm{MHz}$ using $\mathrm{CDCl}_{3}$ or DMSO as solvent and TMS as internal standard. Melting points were measured with an X-5 micro-melting point apparatus and are uncorrected. Fourier transform infrared (FT-IR) spectra of all samples were recorded using a Bruker Vertex 80 . The thermal stability of the samples was evaluated by thermogravimetric analysis (Mettler Toledo TGA /SDTA851E, Switzerland) under an nitrogen $\left(\mathrm{N}_{2}\right)$ atmosphere over the temperature range of $30 \sim 800{ }^{\circ} \mathrm{C}$ in flowing $\mathrm{N}_{2}$ at a heating rate of $5{ }^{\circ} \mathrm{C} \cdot$ $\min ^{-1}$. Morphologies and element content these catalysts were investigated by a Nova NanoSEM 450 scanning electron microscopy (SEM) and AZtec X-Max ${ }^{N} 80$ energy-dispersive spectrometer (EDS). The powder X-ray diffraction (XRD) patterns of the samples were recorded by a BRUKER D8 ADVANCE X-ray diffractometer using $\mathrm{Cu}$ $\mathrm{K} \alpha$ radiation. X-ray photoelectron spectroscopic (XPS) experiment was performed on a Thermo scientific ESCALAB 250Xi electron spectrometer. The $\mathrm{Cu}$ amount contents of these catalysts was estimated by inductively coupled plasma atomic emission spectrometry (ICP-AES) using perkin-Elmer optima $8000 \mathrm{dv}$.

\subsection{Catalyst preparation}

$\mathrm{CS}$ supported copper salts $\left(\mathrm{CuSO}_{4}\right.$ and $\left.\mathrm{Cu}(\mathrm{OAc})_{2}\right)$ were synthesized according to the following procedure: the catalyst was prepared by suspending chitosan in an aqueous solution of $\mathrm{CuSO}_{4}$ and $\mathrm{Cu}(\mathrm{OAc})_{2}$ for $3 \mathrm{~h}$ under neutral 
conditions at $50{ }^{\circ} \mathrm{C}$. After adsorption of the copper, the solid was preconditioned by washing thoroughly to remove any loose $\mathrm{Cu}$ compounds and dried under vacuum at $50{ }^{\circ} \mathrm{C}$ overnight to give the chitosan@ copper catalyst.

Preparation of CS@CuI: The chitosan (1 g) was dispersed in $15 \mathrm{~mL}$ of methanol by stirring at room temperature for $15 \mathrm{~min}$. In another beaker, a solution of $\mathrm{CuSO}_{4}{ }^{\bullet}$ $5 \mathrm{H}_{2} \mathrm{O}(0.125 \mathrm{~g}$ in $15 \mathrm{~mL}$ of methanol) was prepared and this solution was added dropwise into the above suspension under stirring. The mixture was stirred at room temperature for $5 \mathrm{~h}$. Then, the reaction mixture was filtrated and the resulting solid was washed with methanol several times to remove impurities and dried. In the next stage, the obtained blue solid was dispersed in $15 \mathrm{~mL}$ of methanol by stirring at room temperature and a solution of $\mathrm{NaI}$ (1.5 mmol in $15 \mathrm{~mL}$ of methanol) was added dropwise into this mixture under stirring. The reaction mixture was stirred at room temperature for $5 \mathrm{~h}$. Afterward, the solid product was isolated by filtration and washed with methanol several times to remove impurities and dried at room temperature.

Preparation of $\mathrm{CS} @ \mathrm{Cu}_{2} \mathrm{O}: 0.1 \mathrm{~g}$ of $\mathrm{Cu}_{2} \mathrm{O}$ nanoparticle and $1 \mathrm{~g}$ of chitosan were then dispersed in the above 20 $\mathrm{mL}$ of toluene and sonicated to obtain a uniform suspension. The suspension was vigorously stirred by means of ultrasonic at room temperature for $60 \mathrm{~min}$ to ensure enough $\mathrm{Cu}_{2} \mathrm{O}$ nanoparticle adsorbed on the surface of chitosan. After stirring, products were collected by filtration, washed with alcohol several times, and finally dried under vacuum at $50{ }^{\circ} \mathrm{C}$ overnight to give the chitosan $@ \mathrm{Cu}_{2} \mathrm{O}$.

\subsection{Characterization of catalysts}

Catalysts have been characterized by FT-IR, TG, XRD, SEM and ICP-AES. As shown in Figure 2, the pure chitosan powder exhibited characteristic absorption bands of $\mathrm{O}-\mathrm{H}$ and $\mathrm{N}-\mathrm{H}$ stretching vibrations at $3446 \mathrm{~cm}^{-1}$. For the CS@copper catalysts, the peak at $3437 \sim 3415 \mathrm{~cm}^{-1}$ becomes sharper and stronger compared to chitosan. The peaks at around 1074, 1389, 1638, and $2877 \sim 2925 \mathrm{~cm}^{-1}$ correspond to $\mathrm{C}-\mathrm{O}, \mathrm{C}-\mathrm{N}, \mathrm{N}-\mathrm{H}$, and $\mathrm{C}-\mathrm{H}$ stretching models of the chitosan molecules, respectively. The FT-IR of the copper catalysts demonstrated that $\mathrm{NH}_{2}$ and $\mathrm{OH}$ coordinate with the metal $\mathrm{Cu}$. The catalysts were also characterized by TG to study their thermal behavior and stability at elevated temperatures. As shown in Figure 3, the TG curves of all CS@copper catalysts involve three mass loss stages during thermal decomposition. Importantly, the TG showed that these catalysts were stable up to $200{ }^{\circ} \mathrm{C}$, suggesting that their high thermal stability allows them to be compatible with most organic reactions. As shown in Figure 4 , no signals pertaining to the copper metal were detected by XRD, which is similar to previous reports. ${ }^{[31]}$ The SEM analysis showed that $\mathrm{Cu}_{2} \mathrm{O}$ nanoparticles were spherical and the average diameter of the $\mathrm{Cu}_{2} \mathrm{O}$ nanoparticles was about $300 \sim 400 \mathrm{~nm}$, which was consistent with specifications of $\mathrm{Cu}_{2} \mathrm{O}$ nanoparticles purchased (Figure 5a). CuI nanoparticles take on nanorod shape in the SEM picture, its length is about $150 \mathrm{~nm}$ and its diameter is about
$20 \mathrm{~nm}$ (Figure 5c). The SEM analysis showed that the av-

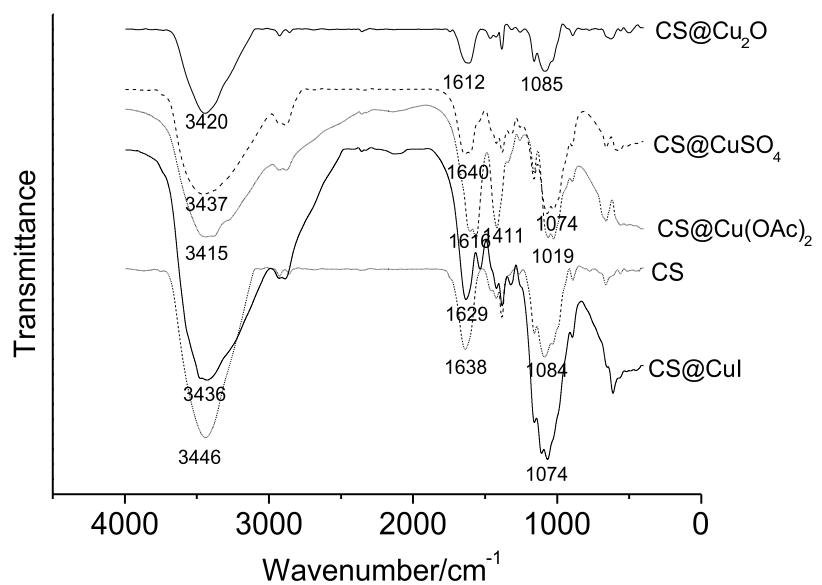

Figure 2 FT-IR spectra of $\mathrm{CS} @ \mathrm{Cu}_{2} \mathrm{O}(\mathbf{A}), \mathrm{CS} @ \mathrm{Cu}(\mathrm{OAc})_{2}(\mathbf{B})$, $\mathrm{CS} @ \mathrm{CuI}(\mathbf{C})$ and $\mathrm{CS} @ \mathrm{CuSO}_{4}(\mathbf{D})$

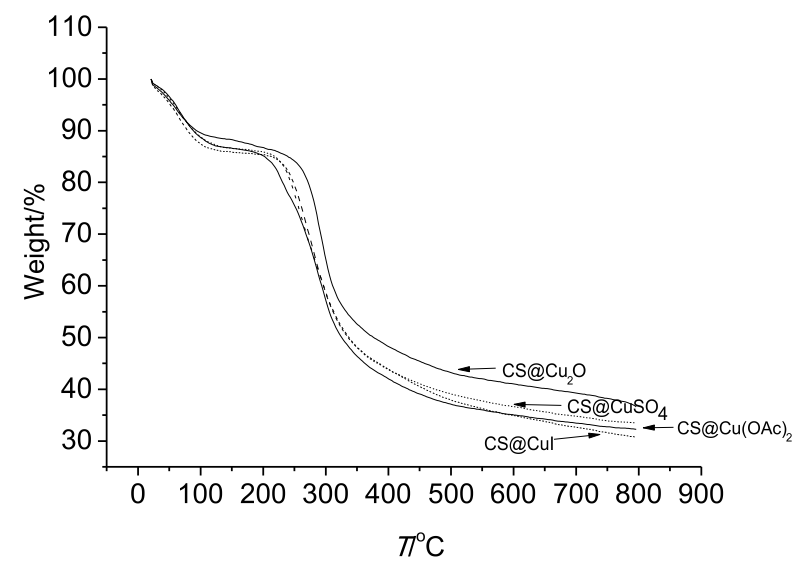

Figure 3 TG Image of $(\mathbf{A}), \mathrm{CS} @ \mathrm{Cu}(\mathrm{OAc})_{2}(\mathbf{B}), \mathrm{CS} @ \mathrm{CuI}(\mathbf{C})$ and CS@ $\mathrm{CuSO}_{4}(\mathbf{D})$

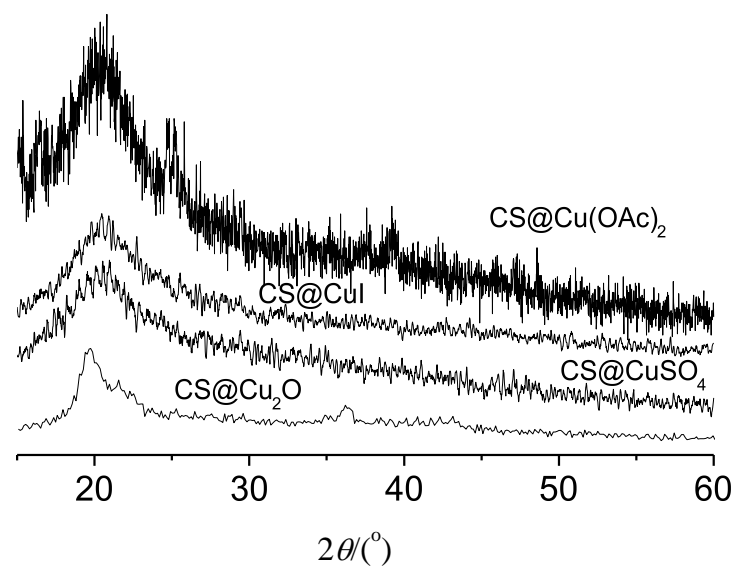

Figure 4 X-ray diffraction of $\mathrm{CS} @ \mathrm{Cu}_{2} \mathrm{O}(\mathbf{A}), \mathrm{CS} @ \mathrm{Cu}(\mathrm{OAc})_{2}$ (B), CS@CuI (C) and CS@CuSO 4 (D)

erage diameter of $\mathrm{Cu}(\mathrm{OAc})_{2}$ and $\mathrm{CuSO}_{4}$ nanoparticles was about $10 \mathrm{~nm}$ and the dispersion of $\mathrm{Cu}$ particles was very good (Figures 5b and 5d). Also, various elements in the structures of $\mathrm{CS} @ \mathrm{Cu}_{2} \mathrm{O}, \mathrm{CS} @ \mathrm{Cu}(\mathrm{OAc})_{2}, \mathrm{CS} @ \mathrm{CuI}$ and $\mathrm{CS} @ \mathrm{CuSO}_{4}$ were characterized by energy dispersive X-ray 
spectroscopy (EDS) obtained from SEM analysis. As can be seen from Figure 5, carbon, nitrogen, oxygen and copper are present in all synthesized catalysts. In addition, catalyst $\mathbf{C}$ contains iodine and catalyst $\mathbf{D}$ contains sulfur. The above elements determined by EDS are consistent with the composition of the prepared catalysts. As shown in the XPS diagram of $\mathrm{CS} @ \mathrm{Cu}_{2} \mathrm{O}$, in the newly prepared $\mathrm{CS} @ \mathrm{Cu}_{2} \mathrm{O}$, copper(I) is almost the only form of copper (Figure 6). The copper loading levels of $\mathrm{CS} @ \mathrm{Cu}_{2} \mathrm{O}$, $\mathrm{CS} @ \mathrm{Cu}(\mathrm{OAc})_{2}, \mathrm{CS} @ \mathrm{CuI}$ and $\mathrm{CS} @ \mathrm{CuSO}_{4}$ measured by ICP-AES were $1.85,1.93,1.82$, and $1.98 \mathrm{mmol}^{\circ} \mathrm{g}^{-1}$, respectively. The used CS@ $\mathrm{Cu}_{2} \mathrm{O}$ was also characterized by infrared spectroscopy. The results are shown in Figure 7. Compared to the infrared spectra of $\mathrm{CS} @ \mathrm{Cu}_{2} \mathrm{O}$, strong absorption peaks were observed at 1592 and $1464 \mathrm{~cm}^{-1}$ of recovered $\mathrm{CS} @ \mathrm{Cu}_{2} \mathrm{O}$, which indicating that a small amount of reactants or products were adsorbed on the catalyst. Finally, the surface morphology of used $\mathrm{CS} @ \mathrm{Cu}_{2} \mathrm{O}$ and valence state of copper were also characterized. As shown in Figure 8, the surface morphology of used $\mathrm{CS} @ \mathrm{Cu}_{2} \mathrm{O}$ has changed due to repeated use, and the $\mathrm{Cu}_{2} \mathrm{O}$ nanoparticles have changed from spherical to flaky. Although copper(I) is still the main form of copper, the content of copper(II) has increased significantly for the same reason.

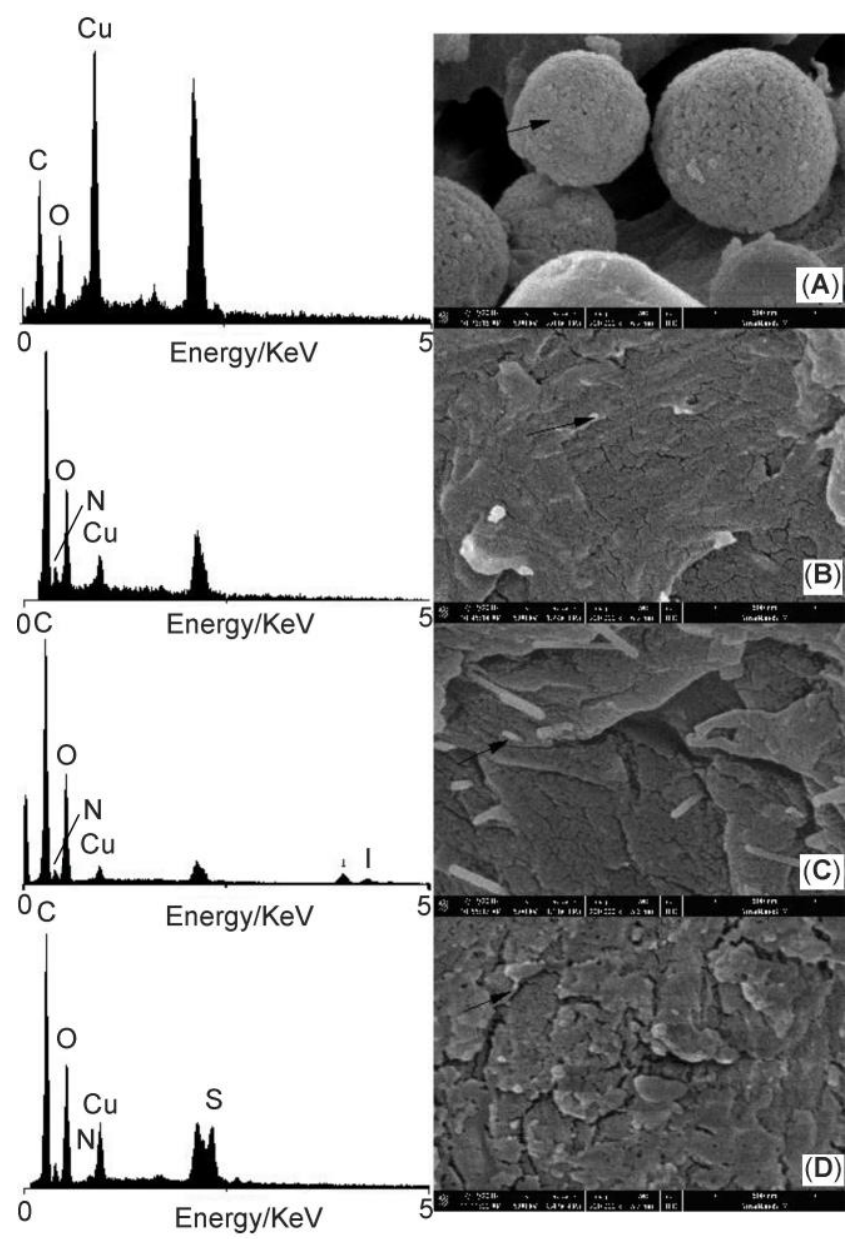

Figure 5 Surface morphology and EDS of $\mathrm{CS} @ \mathrm{Cu}_{2} \mathrm{O}(\mathbf{A})$, $\mathrm{CS} @ \mathrm{Cu}(\mathrm{OAc})_{2}(\mathbf{B}), \mathrm{CS} @ \mathrm{CuI}(\mathbf{C})$ and $\mathrm{CS} @ \mathrm{CuSO}_{4}(\mathbf{D})$

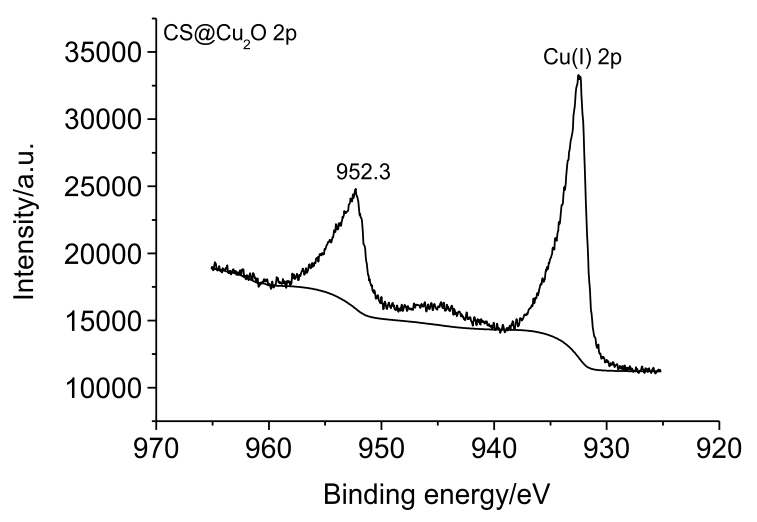

Figure 6 XPS analysis of $\mathrm{CS} @ \mathrm{Cu}_{2} \mathrm{O}$

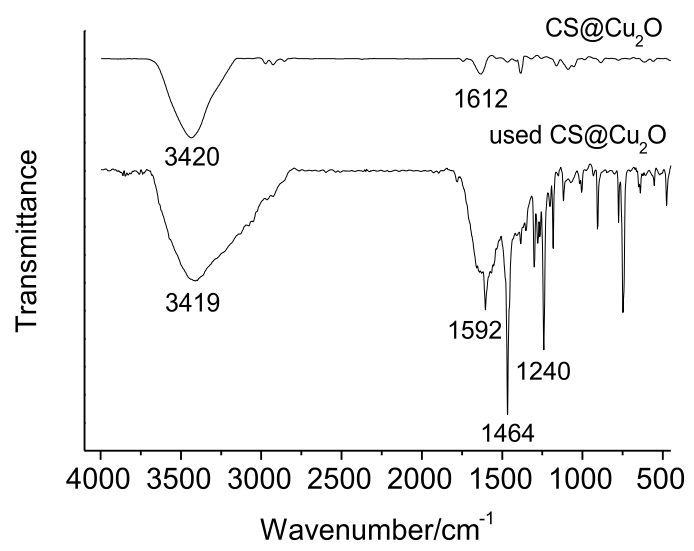

Figure 7 FT-IR spectra of $\mathrm{CS} @ \mathrm{Cu}_{2} \mathrm{O}$ and used $\mathrm{CS} @ \mathrm{Cu}_{2} \mathrm{O}$
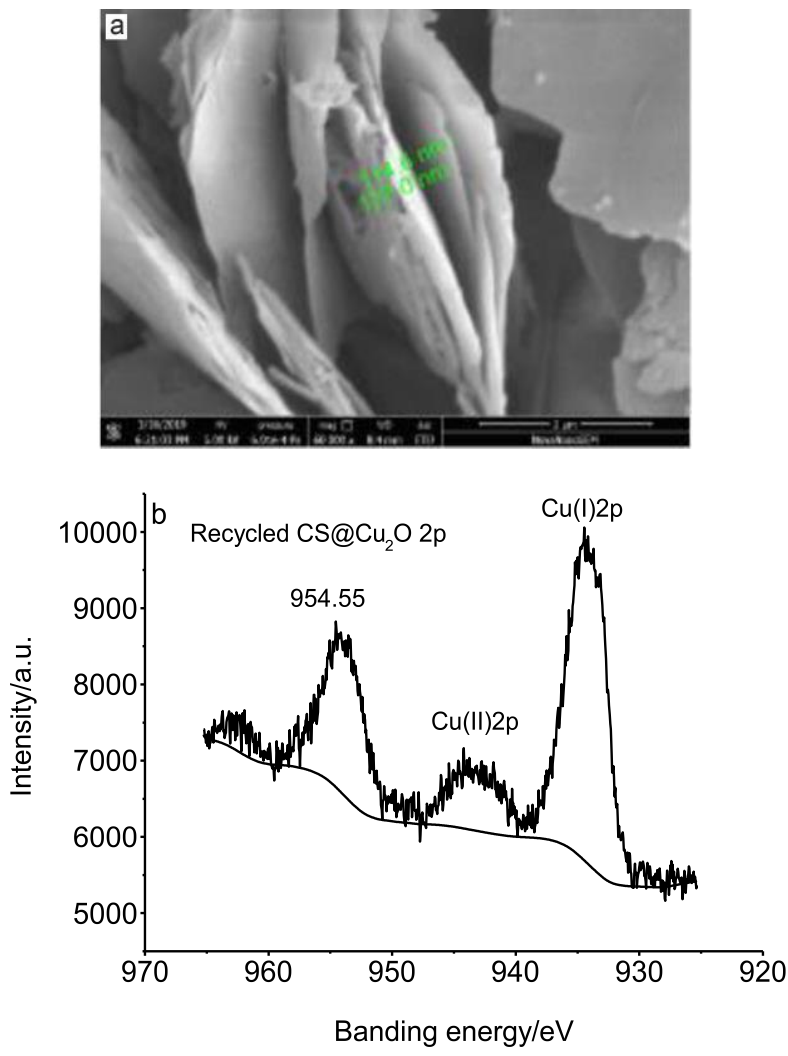

Figure 8 Surface morphology (a) and XPS analysis (b) of recycled $\mathrm{CS} @ \mathrm{Cu}_{2} \mathrm{O}$ 


\subsection{Thermal filtration experiment}

Thermal filtration experiment is usually an important test method to detect the heterogeneity of catalyst. ${ }^{[32]}$ The heterogeneity of $\mathrm{CS} @ \mathrm{Cu}_{2} \mathrm{O}$ was studied by using $O$-arylation of phenol with bromobenzene as template. Firstly, the catalyst was removed by filtration after the reaction proceeded at $110{ }^{\circ} \mathrm{C}$ for $2 \mathrm{~h}$, and the filtrate was further heated for $16 \mathrm{~h}$ under the same conditions. GC analysis showed that $23 \%$ yield was obtained after $2 \mathrm{~h}$ of reaction and $25 \%$ yield was obtained after $18 \mathrm{~h}$ of reaction. Clearly, no appreciable reaction took place after removal of the catalyst. The above experimental results distinctly showed that no active species leached into the liquid phase and provides direct evidence for the heterogeneity of the present catalyst system.

\subsection{Catalytic test}

Typical representative experimental procedure: CS@ $\mathrm{Cu}_{2} \mathrm{O}([\mathrm{Cu}]=1 \mathrm{~mol} \%)$, 2-naphthol $(2.0 \mathrm{mmol}, 288 \mathrm{mg})$ and $\mathrm{K}_{3} \mathrm{PO}_{4}(638 \mathrm{mg}, 3.0 \mathrm{mmol})$ were added to a screw-capped Schlenk tube under argon. The tube was then evacuated and backfilled with argon (three cycles). Chlorobenzene $(1 \mathrm{mmol}, 0.10 \mathrm{~mL})$ and dry DMF $(0.5 \mathrm{~mL})$ were added by syringe at room temperature. The reaction mixture was stirred at needed temperature $\left(110{ }^{\circ} \mathrm{C}\right)$ for $18 \mathrm{~h}$. The reaction mixture was allowed to reach room temperature and then diluted with dichloromethane and $\mathrm{H}_{2} \mathrm{O}(5$ $\mathrm{mL} / 5 \mathrm{~mL}$ ). The catalyst was obtained by filtration and washed with $5 \mathrm{~mL}$ of ethylacetate. The organic layer was collected, then removed in vacuo, and the residue was purified by column chromatography on silica gel to afford the desired product.

Diphenylether: ${ }^{[6]}$ Colorless liquid; ${ }^{1} \mathrm{H}$ NMR (400 MHz, $\left.\mathrm{CDCl}_{3}\right) \delta: 6.99 \sim 7.01(\mathrm{~m}, 4 \mathrm{H}), 7.07 \sim 7.11(\mathrm{~m}, 2 \mathrm{H})$, $7.30 \sim 7.34(\mathrm{~m}, 4 \mathrm{H})$.

4-Methoxy-diphenylether: ${ }^{[24]}$ Colorless liquid; ${ }^{1} \mathrm{H}$ NMR $\left(400 \mathrm{MHz} \mathrm{CDCl}_{3}\right) \delta: 3.82(\mathrm{~s}, 3 \mathrm{H}), 6.90 \sim 6.93(\mathrm{~m}, 2 \mathrm{H})$, $6.97 \sim 7.09$ (m, 5H), $7.31 \sim 7.35(\mathrm{~m}, 2 \mathrm{H})$.

2-Naphthyl phenylether: ${ }^{[11]}$ Pale yellow colored solid; m.p. $45 \sim 48{ }^{\circ} \mathrm{C} ;{ }^{1} \mathrm{H}$ NMR (400 $\left.\mathrm{MHz}, \mathrm{CDCl}_{3}\right) \delta: 7.17 \sim$ $7.25(\mathrm{~m}, 3 \mathrm{H}), 7.35 \sim 7.38(\mathrm{~m}, 1 \mathrm{H}), 7.43 \sim 7.55(\mathrm{~m}, 5 \mathrm{H})$, $7.78(\mathrm{~d}, J=8 \mathrm{~Hz}, 1 \mathrm{H}), 7.90 \sim 7.91(\mathrm{~m}, 2 \mathrm{H})$.

4-Methyl-diphenylether: ${ }^{[6]}$ Colorless liquid; ${ }^{1} \mathrm{H}$ NMR $\left(400 \mathrm{MHz}, \mathrm{CDCl}_{3}\right) \delta: 2.41(\mathrm{~s}, 3 \mathrm{H}), 6.90 \sim 6.92(\mathrm{~m}, 2 \mathrm{H})$, $6.96(\mathrm{~d}, J=8.0 \mathrm{~Hz}, 2 \mathrm{H}), 7.02 \sim 7.05(\mathrm{~m}, 1 \mathrm{H}), 7.10(\mathrm{~d}, J=$ $8.4 \mathrm{~Hz}, 2 \mathrm{H}), 7.28(\mathrm{t}, J=8.4 \mathrm{~Hz}, 2 \mathrm{H})$.

4-Methyl-4'-methoxy-diphenylether: ${ }^{[33]}$ White solid; m.p. $45 \sim 46{ }^{\circ} \mathrm{C} ;{ }^{1} \mathrm{H}$ NMR (400 MHz, $\mathrm{CDCl}_{3}$ ) $\delta: 2.30(\mathrm{~s}$, $3 \mathrm{H}), 3.77$ (s, 3H), $6.84(\mathrm{~d}, J=8 \mathrm{~Hz}, 4 \mathrm{H}), 6.94(\mathrm{~d}, J=8.4$ $\mathrm{Hz}, 2 \mathrm{H}), 7.08$ (d, $J=8.4 \mathrm{~Hz}, 2 \mathrm{H})$.

4-Chloro-4'-methyl diphenylether: ${ }^{[34]}$ Colorless liquid; ${ }^{1} \mathrm{H}$ NMR (400 MHz, $\left.\mathrm{CDCl}_{3}\right) \delta: 2.29(\mathrm{~s}, 3 \mathrm{H}), 6.85$ (d, $J=$ $8.4 \mathrm{~Hz}, 4 \mathrm{H}), 7.09$ (d, $J=8 \mathrm{~Hz}, 2 \mathrm{H}), 7.21(\mathrm{~d}, J=8.4 \mathrm{~Hz}$, $2 \mathrm{H})$.

1-(4'-Phenoxyphenyl)ethenone: ${ }^{[8]}$ Pale yellow solid; m.p. 52 53 ${ }^{\circ} \mathrm{C} ;{ }^{1} \mathrm{H}$ NMR (400 MHz, $\left.\mathrm{CDCl}_{3}\right) \delta: 2.57$ (s, $3 \mathrm{H}), 7.00(\mathrm{~d}, J=8.4 \mathrm{~Hz}, 2 \mathrm{H}), 7.07$ (d, $J=8.0 \mathrm{~Hz}, 2 \mathrm{H}), 7.20$ $(\mathrm{t}, \quad J=7.2 \mathrm{~Hz}, 1 \mathrm{H}), 7.40(\mathrm{t}, J=7.6 \mathrm{~Hz}, 2 \mathrm{H}), 7.94(\mathrm{~d}, J=$ $8.4 \mathrm{~Hz}, 2 \mathrm{H})$.

4-Chloro-4'-acetyldiphenylether: ${ }^{[34]}$ Pale yellow solid; m.p. 66 $67{ }^{\circ} \mathrm{C} ;{ }^{1} \mathrm{H}$ NMR $\left(400 \mathrm{MHz}, \mathrm{CDCl}_{3}\right) \delta: 2.58$ (s, $3 \mathrm{H}), 6.98 \sim 7.02(\mathrm{~m}, 4 \mathrm{H}), 7.35(\mathrm{~d}, J=8.4 \mathrm{~Hz}, 2 \mathrm{H}), 7.95(\mathrm{~d}$, $J=8.4 \mathrm{~Hz}, 2 \mathrm{H})$.

1-Phenyl-1H-imidazole: ${ }^{[35]}$ Pale yellow oily liquid; ${ }^{1} \mathrm{H}$ NMR (DMSO- $\left.d_{6}, 400 \mathrm{MHz}\right) \delta: 8.27(\mathrm{~s}, 1 \mathrm{H}), 7.76(\mathrm{~s}, 1 \mathrm{H})$, $7.68 \sim 7.65(\mathrm{~m}, 2 \mathrm{H}), 7.55 \sim 7.51(\mathrm{~m}, 2 \mathrm{H}), 7.39 \sim 7.35(\mathrm{~m}$, $1 \mathrm{H}), 7.13(\mathrm{~s}, 1 \mathrm{H})$.

1-Phenyl-1H-1,2,4-triazole:: ${ }^{[35]}$ Yellow solid; m.p. 46 $47{ }^{\circ} \mathrm{C} ;{ }^{1} \mathrm{H}$ NMR (DMSO- $\left.d_{6}, 400 \mathrm{MHz}\right) \delta: 9.31(\mathrm{~s}, 1 \mathrm{H}, \mathrm{N}=$ $\mathrm{CHN}), 8.25(\mathrm{~s}, 1 \mathrm{H}), 7.88(\mathrm{~d}, J=8.4 \mathrm{~Hz}, 2 \mathrm{H}, \mathrm{PhH}), 7.59 \sim$ 7.55(m, 2H, PhH), 7.43 7.41(m, 1H, $\mathrm{PhH})$.

1-Phenyl-1H-benzo[d]imidazole: ${ }^{[36]}$ Pale yellow oily liquid; ${ }^{1} \mathrm{H}$ NMR $\left(\mathrm{CDCl}_{3}, 400 \mathrm{MHz}\right) \delta: 7.98(\mathrm{~s}, 1 \mathrm{H}), 7.78 \sim$ $7.76(\mathrm{~m}, 1 \mathrm{H}), 7.71 \sim 7.61(\mathrm{~m}, 5 \mathrm{H}, \mathrm{PhH}), 7.53 \sim 7.49(\mathrm{~m}$, $1 \mathrm{H}), 7.37 \sim 7.30(\mathrm{~m}, 2 \mathrm{H}, \mathrm{PhH})$.

1-( $p$-Tolyl)- $1 H$-imidazole: ${ }^{[35]}$ Pale yellow oily liquid; ${ }^{1} \mathrm{H}$ NMR (DMSO- $\left.d_{6}, 400 \mathrm{MHz}\right) \delta: 8.23(\mathrm{~s}, 1 \mathrm{H}), 7.71(\mathrm{~s}, 1 \mathrm{H})$, $7.53(\mathrm{~d}, J=7.2 \mathrm{~Hz}, 2 \mathrm{H}), 7.32(\mathrm{~m}, J=7.6 \mathrm{~Hz}, 2 \mathrm{H}), 7.10$ (s, $1 \mathrm{H}), 2.345$ (s, 3H).

1-(p-Tolyl)-1H-1,2,4-triazole: ${ }^{[35]}$ Yellow solid; m.p. $65 \sim 67{ }^{\circ} \mathrm{C} ;{ }^{1} \mathrm{H}$ NMR $\left(\mathrm{CDCl}_{3}, 400 \mathrm{MHz}\right) \delta: 8.51(\mathrm{~s}, 1 \mathrm{H})$, $8.091(\mathrm{~s}, 1 \mathrm{H}), 7.551$ (d, $J=8.4 \mathrm{~Hz}, 2 \mathrm{H}), 7.304$ (d, $J=8.0$ $\mathrm{Hz}, 2 \mathrm{H}), 2.416$ (s, 3H).

1-( $p$-Tolyl)-1H-benzo[d]imidazole: ${ }^{[36]}$ Pale yellow oily liquid; ${ }^{1} \mathrm{H}$ NMR (DMSO- $\left.d_{6}, 400 \mathrm{MHz}\right) \delta: 8.53(\mathrm{~s}, 1 \mathrm{H})$, $7.81 \sim 7.79(\mathrm{~m}, 1 \mathrm{H}), 7.59 \sim 7.54(\mathrm{~m}, 3 \mathrm{H}), 7.42(\mathrm{~d}, J=8.0$ $\mathrm{Hz}, 2 \mathrm{H}), 7.35 \sim 7.31(\mathrm{~m}, 2 \mathrm{H}), 2.41(\mathrm{~s}, 3 \mathrm{H})$.

1-( $p$-Tolyl)-1H-indole: ${ }^{[35]}$ Yellow oily liquid; ${ }^{1} \mathrm{H}$ NMR $\left(\mathrm{DMSO}-d_{6}, 400 \mathrm{MHz}\right) \delta: 7.66(\mathrm{~d}, J=7.6 \mathrm{~Hz}, 1 \mathrm{H}), 7.58 \sim$ $7.56(\mathrm{~m}, 1 \mathrm{H}), 7.52(\mathrm{~d}, J=8.0 \mathrm{~Hz}, 1 \mathrm{H}), 7.47 \sim 7.44(\mathrm{~m}, 2 \mathrm{H})$, $7.38 \sim 7.34(\mathrm{~m}, 2 \mathrm{H}), 7.20 \sim 7.10(\mathrm{~m}, 2 \mathrm{H}), 6.69 \sim 6.68(\mathrm{~m}$, $1 \mathrm{H}), 2.38$ (s, 3H).

1-(4-Methoxyphenyl)-1H-1,2,4-triazole: ${ }^{[37]}$ Yellow solid; m.p. $119 \sim 121{ }^{\circ} \mathrm{C} ;{ }^{1} \mathrm{H}$ NMR (DMSO- $\left.d_{6}, 400 \mathrm{MHz}\right) \delta$ : 8.46 (s, 1H), 8.09 (d, 1H), 7.57 (d, J=9.2 Hz, 2H), 7.02 (d, $J=9.2 \mathrm{~Hz}, 2 \mathrm{H}), 3.87$ (s, 3H).

1-(p-Methoxyphenyl)-1H-benzo[d]imidazole: ${ }^{[38]}$ Yellow solid; m.p. 93 95 ${ }^{\circ} \mathrm{C}$; ${ }^{1} \mathrm{H}$ NMR (DMSO- $\left.d_{6}, 400 \mathrm{MHz}\right) \delta$ : $8.48(\mathrm{~s}, 1 \mathrm{H}), 7.79 \sim 7.77(\mathrm{~m}, 1 \mathrm{H}), 7.59(\mathrm{~d}, J=8.8 \mathrm{~Hz}, 2 \mathrm{H})$, $7.53 \sim 7.51(\mathrm{~m}, 1 \mathrm{H}), 7.34 \sim 7.20(\mathrm{~m}, 2 \mathrm{H}), 7.18(\mathrm{~d}, J=8.8$ $\mathrm{Hz}, 2 \mathrm{H}), 3.85$ (s, 3H).

4-(1H-imidazol-1-yl)benzonitrile: ${ }^{[39]}$ Yellow solid; m.p. $145 \sim 147{ }^{\circ} \mathrm{C} ;{ }^{1} \mathrm{H}$ NMR $\left(\mathrm{CDCl}_{3}, 400 \mathrm{MHz}\right) \delta: 7.88(\mathrm{~s}, 1 \mathrm{H})$, $7.46 \sim 7.75(\mathrm{~m}, 4 \mathrm{H}), 7.27(\mathrm{~s}, 1 \mathrm{H}), 7.21(\mathrm{~d}, J=8.0 \mathrm{~Hz}, 1 \mathrm{H})$.

4-(1H-1,2,4-triazol-1-yl)benzonitrile: ${ }^{[40]}$ Yellow solid; m.p. $158 \sim 160{ }^{\circ} \mathrm{C} ;{ }^{1} \mathrm{H}$ NMR $\left(\mathrm{CDCl}_{3}, 400 \mathrm{MHz}\right) \delta: 8.67$ (s, $1 \mathrm{H}), 8.16(\mathrm{~s}, 1 \mathrm{H}), 7.88 \sim 7.81(\mathrm{~m}, 4 \mathrm{H})$.

4-(1H-Benzo[d]imidazol-1-yl)benzonitrile: ${ }^{[41]} \quad$ Yellow solid; m.p. $159 \sim 161{ }^{\circ} \mathrm{C} ;{ }^{1} \mathrm{H}$ NMR $\left(\mathrm{CDCl}_{3}, 400 \mathrm{MHz}\right) \delta$ : $8.17(\mathrm{~s}, 1 \mathrm{H}), 7.89 \sim 7.92(\mathrm{~m}, 3 \mathrm{H}), 7.71 \sim 7.68(\mathrm{~m}, 2 \mathrm{H})$, $7.60 \sim 7.57(\mathrm{~m}, 1 \mathrm{H}), 7.41 \sim 7.37(\mathrm{~m}, 2 \mathrm{H})$.

1-(o-Tolyl)- $1 H$-imidazole: ${ }^{[36]}$ Pale yellow oily liquid; ${ }^{1} \mathrm{H}$ $\mathrm{NMR}\left(\mathrm{CDCl}_{3}, 400 \mathrm{MHz}\right) \delta$ : $1 \mathrm{H} \mathrm{NMR}\left(\mathrm{CDCl}_{3}, 400 \mathrm{MHz}\right) \delta$ : $7.56(\mathrm{~s}, 1 \mathrm{H}), 7.31 \sim 7.28(\mathrm{~m}, 2 \mathrm{H}), 7.25 \sim 7.22(\mathrm{~m}, 2 \mathrm{H})$, 
$7.19 \sim 7.15(\mathrm{~m}, 2 \mathrm{H}), 2.12(\mathrm{~s}, 3 \mathrm{H})$

1-(o-Tolyl)-1H-1,2,4-triazole: ${ }^{[42]}$ Yellow oily liquid; ${ }^{1} \mathrm{H}$ NMR $\left(\mathrm{CDCl}_{3}, 400 \mathrm{MHz}\right) \delta: 8.27(\mathrm{~s}, 1 \mathrm{H}), 8.13(\mathrm{~s}, 1 \mathrm{H})$, $7.43 \sim 7.27(\mathrm{~m}, 4 \mathrm{H}), 2.24(\mathrm{~s}, 3 \mathrm{H})$.

1-(o-Tolyl)- $1 H$-benzo[d]imidazole: ${ }^{[36]}$ Yellow oily liquid; ${ }^{1} \mathrm{H}$ NMR $\left(\mathrm{CDCl}_{3}, 400 \mathrm{MHz}\right) \delta: 7.98(\mathrm{~s}, 1 \mathrm{H}), 7.893(\mathrm{~d}$, $J=8.0 \mathrm{~Hz}, 1 \mathrm{H}), 7.45 \sim 7.43(\mathrm{~m}, 2 \mathrm{H}), 7.38 \sim 7.29(\mathrm{~m}, 4 \mathrm{H})$, $7.144(\mathrm{~d}, J=7.6 \mathrm{~Hz}, 1 \mathrm{H}), 2.11(\mathrm{~s}, 3 \mathrm{H})$.

Supporting Information. The Supporting Information is available free of charge via the Internet at http://siocjournal.cn/.

\section{References}

[1] For reviews, see:

(a) Lindley, J. Tetrahedron 1984, 40, 1433.

(b) Theil, F. Angew. Chem. Int. Ed. 1999, 38, 2345.

(c) Sawyer, J. S. Tetrahedron 2000, 56, 5045.

(d) Thomas, A. W.; Ley, S. V. Angew. Chem. Int. Ed. 2003, 42, 5400 .

(e) Kunz, K.; Scholz, U.; Ganzer, D. Synlett. 2003, 15, 2428.

(f) Beletskaya, I. P.; Cheprakov, A. V. Coord. Chem. Rev. 2004, 248, 2337.

[2] For selected examples of medicinally important diaryl ethers, see: (a) Jung, M. E.; Rohloff, J. C. J. Org. Chem. 1985, 50, 4909.

(b) Singh, S. B.; Pettit, G. R. J. Org. Chem. 1990, 55, 2797.

(c) Deshpande, V. E.; Gohkhale, N. J. Tetrahedron Lett. 1992, 33, 4213 .

(d) Evans, D. A.; DeViries, K. M. In Glycopeptide Antibiotics, Drugs and the Pharmaceutical Sciences, Ed.: Nagarajan, R., Marcel Decker, New York, 1994, p. 63.

(e) Zenitani, S.; Tashiro, S.; Shindo, K.; Nagai, K.; Suzuki, K.; Imoto, M.; Gerfelin, A. J. Antibiot 2003, 56, 617.

(f) Cristau, P.; Vors, J. P.; Zhu, J. Tetrahedron 2003, 59, 7859

(g) Qian, C. W.; Pang, Y.; Fang, D.; Zong, Q. Chin. J. Pestic. Sci. 2013, 15, 44 (in Chinese).

[3] (a) Ullmann, F. Dtsch, Ber. Chem. Ges 1904, 37, 853.

(b) Ullmann, F. Dtsch, Ber. Chem. Ges. 1903, 36, 2382.

[4] (a) Mann, G.; Hartwig, J. F. Tetrahedron Lett. 1997, 46, 8005.

(b) Palucki, M.; Wolfe, J. P.; Bukhwald, S. L. J. Am. Chem. Soc. 1996, 118,10333 .

(c) Mann, G.; Hartwig, J. F. J. Am. Chem. Soc. 1996, $118,13109$.

(d) Aranyos, A.; Old, D. W.; Kiyomori, A.; Wolfe, J. P.; Sadighi, J. P.; Buchwald, S. L. J. Am. Chem. Soc. 1999, 121, 4369.

(e) Mann, G.; Hartwig, J. F. J. Org. Chem. 1997, 62, 5413.

(f) Palucki, M. J.; Wolfe, P.; Buchwald, S. J. Am. Chem. Soc. 119, 3395.

(g) Widenhoefer, R. A.; Zhong, H. A.; Buchwald, S. L. J. Am. Chem. Soc. 1997, 119, 6787.

[5] Marcoux, J. F.; Doye, S.; Buchwald, S. L. J. Am. Chem. Soc. 1997, 119, 10539.

[6] Ma, D.; Cai, Q. Org. Lett. 2003, 5, 3799.

[7] Chen, Y. J.; Chen, H. H. Org. Lett. 2006, 8, 5609.

[8] Rao, H.; Jin, Y.; Fu, H.; Jiang, Y.; Zhao, Y. Chem.-Eur. J. 2006, 12, 3636.

[9] Wolter, M.; Nordmann, G.; Job, G. E.; Buchwald, S. L. Org. Lett. 2002, 4, 973 .
[10] Gujadhur, R. K.; Bates, C. G.; Venkataraman, D. Org. Lett. 2001, 3, 4315.

[11] Qian, C.; Zong, Q.; Fang, D. Chin. J. Chem. 2012, 30, 199.

[12] Qian, C.; Xu, S.; Fang, D.; Zong, Q. Chin. J. Chem. 2012, 30, 1881.

[13] Buck, E.; Song, Z.; Tschaen, D.; Dormer, P. G.; Volante, R. P.; Reider, P. J. Org. Lett. 2002, 4, 1623.

[14] Lv, X.; Bao, W. J. Org. Chem. 2007, 72, 3863.

[15] Qian, C.; Qin, L.; Zong, Q.; Wu, L.; Fang, D. Bull. Korean Chem. Soc. 2013, 34, 3915.

[16] Qian, C.; Lv, W.; Zong, Q.; Wang, M.; Fang, D. Chin. Chem. Lett. 2014, 25, 337.

[17] Gawande, M. B.; Goswami, A.; Felpin, F.; Asefa, T.; Huang, X.; Silva, R.; Zou, X.; Zboril, R. R.; Varma, S. Chem. Rev. 2016, 116, 3722 .

[18] Zhao, H.; Xu, J.; Wang, T. Appl. Catal. A: Gen. 2015, 502, 188.

[19] Honraedt, A.; Le Callonnec, F.; Le Grognec, E.; Fernandez, V.; Felpin, F.-X. J. Org. Chem. 2013, 78, 4604.

[20] Mondal, P.; Sinha, A.; Salam, N.; Roy, A. S.; Jana, N. R.; Islam, S. M. RSC Adv. 2013, 3, 5615.

[21] Hajipour, A. R.; Dordahan, F.; Rafiee, F.; Mahdavi, M. Appl. Organomet. Chem. 2014, 28, 809.

[22] Nador, F.; Volpe, M. A.; Alonso, F.; Radivoy, G. Tetrahedron 2014, 70,6082 .

[23] Baig, R. B. N.; Varma, R. S. Chem. Commun. 2012, 48, 2582.

[24] Sharma, R. K.; Gaur, R.; Yadav, M.; Rathi, A. K.; Pechousek, J.; Petr, M.; Zboril, R.; Gawande, M. B. ChemCatChem 2015, 7, 3495.

[25] Gopiraman, M.; Ganesh Babu, S.; Khatri, Z.; Kai, W.; Kim, Y. A.; Endo, M.; Karvembu, R.; Kim, I. S. Carbon 2013, 62, 135.

[26] (a) Carlo, G. Di; Curulli, A.; R. Toro, G.; Bianchini, C.; De Caro, T.; Padeletti, G.; Zane, D.; Ingo, G. M. Langmuir 2012, 28, 5471. (b) Yang, Y.-H.; Cui, J.-H.; Zheng, M.-T.; Hu, C.-F.; Tan, S.-Z.; Xiao, Y.; Yang, Q.; Liu, Y.-L. Chem. Commun. 2012, 48, 380.

[27] Hardy, J. J. E.; Hubert, S.; Macquarrie, D. J.; Wilson, A. J. Green Chem. 2004, 6, 53.

[28] Kadib, A. E.; Molvinger, K.; Bousmina M.; Brunel, D. Org. Lett. 2010, 12, 948.

[29] Makhubela, B. C. E.; Jardine, A.; Smith, G. S. Green Chem. 2012, 14, 338 .

[30] Baig, R. B. N.; Varma, R. S. Green Chem. 2013, 15, 1834.

[31] Shen, C.; Xu, J.; Yu, W.; Zhang P. Green Chem. 2014, 16, 3007.

[32] Collins, G.; Schmidt, M.; O’Dwyer, C.; McGlacken, G.; Holmes, J. ACS Catal. 2014, 4, 3105.

[33] Marcoux, J.; Doye, S.; Buchwald S. J. Am. Chem. Soc. 1997, 119, 10539.

[34] Takashi, M.; Fumitoshi, Y.; Masanori, S.; Kenji, K.; Hiroaki, S.; Masami, S.; Tsutomu, F. Synlett 2009, 2457.

[35] Li, Z.; Meng, F.; Zhang, J.; Xie, J.; Dai, B. Org. Biomol. Chem. 2016, $14,10861$.

[36] Janíkova, K.; Jedinak, L.; Volna, T.; Canka, P. Tetrahedron 2018 , 74(5): 606

[37] Kantam, M. L.; Venkanna, G. T.; Sridhar, C.; Sreedhar, B.; Choudary, B. M. J. Org. Chem. 2006, 71, 9522.

[38] Zhang, Z. J.; Mao, J. C.; Zhu, D.; Wu, F.; Chen, H. L.; Wan, B. S. Tetrahedron 2006, 62, 4435.

[39] Zhang, X.; Xia, A.; Chen, H.; Liu, Y. Org. Lett. 2017, 19(8), 2118.

[40] Yin, W.; Wang, C.; Huang, Y. Org. Lett. 2013, 15(8), 1850.

[41] Hosseini-Sarvari, M.; Razmi Z. RSC Adv. 2014, 4, 44105.

[42] Shelke, G. M.; Rao, V. K.; Jha, M.; Cameron, T. S.; Kumar, A. Synlett. 2015, 26(3), 404. 